\title{
CARA PANDANG (WORLD VIEW) ORANG ATONI PAH METO DALAM PERSPEKTIF KOMUNIKASI RITUAL
}

\author{
Yermia Djefri Manafe \\ Ilmu Komunikasi, Fakultas Ilmu Sosial dan Ilmu Politik, FISIP, Universitas Nusa Cendana \\ Jl. Adi Sucipto, Penfui, P.O. Box 104, Kupang 85001, Nusa Tenggara Timur
}

\begin{abstract}
ABSTRAK
Pandangan hidup atau pandangan dunia masyarakat adat Atoni Pah Meto sangat berkaitan dengan orientasi budaya yang mereka anut berdasarkan sistem kepercayaan mereka terhadap hal-hal seperti Tuhan, kemanusiaan, alam, alam semesta, dan masalah-masalah filosofis yang berkaitan dengan keberadaan masyarakat adat Atoni Pah Meto itu sendiri. Pandangan dunia masyarakat adat Atoni Pah Meto membantu mereka untuk mengetahui posisi dan tingkah mereka dalam alam semesta. Isuisu pandangan dunia bersifat abadi dan merupakan landasan paling mendasar dari suatu budaya. Pandangan dunia masyarakat adat Atoni Pah Meto merupakan nilai-nilai budaya yang menentukan bagaimana mereka harus bersikap. Nilainilai budaya ini menentukan perilaku-perilaku mana yang penting dan perilaku-perilaku mana yang harus dihindari. Nilainilai budaya ini merupakan seperangkat aturan terorganisasi untuk membuat pilihan-pilihan dan mengurangi konflik. Berkenaan dengan pandangan dunia Atoni Pah Meto, maka perlu dibahas untuk mendapatkan informasi tentang keyakinan dan sikap hidup masyarakat adat Atoni Pah Meto, yakni melalui: faot kanaf dan oe kanaf, hau teas atau hau monef, sonaf (rumah adat suku), dan sistem pengelolaan sumber daya alam sebagai simbol budaya yang sangat dihormati, bahkan sangat dikeramatkan oleh masing-masing suku pemiliknya.
\end{abstract}

Kata kunci: World View, Masyarakat Adat, Atoni Pah Meto, Ritual Pertanian.

\begin{abstract}
Philosophy of life or Perspective of Atoni Pah Meto indigenous society's world is associated with cultural orientation that they professed based on their belief system to things like God, humanity, nature, the universe, and philosophical issues related to the existence of Atoni Pah Meto indigenous society itself. World view of Atoni Pah Meto indigenous society's world helps them to see positions and their behavior in the universe. The issues of world view are timeless and the most fundamental foundation of a culture. World view of Atoni Pah Meto indigenous society's world is the cultural values that determine how they should behave. These cultural values determine behaviors which are important and which behaviors should be avoided. These Cultural values is an organized set of rules to make choices and reduce conflict. Regard to world view of Atoni Pah Meto, then it needs to be discussed to get information about the beliefs and attitudes of Atoni Pah Meto indigenous society from faot kanaf and oe kanaf, hau teas or hau monef, sonaf (custom tribe house), and natural resource management system as a highly respected cultural symbol, in fact so hallowed by each tribe the owners.
\end{abstract}

Keywords: World View, Indigenous Society, Atoni Pah Meto, Agricultural Ritual.

\section{PENDAhULUAN}

Pandangan hidup atau pandangan dunia masyarakat adat Atoni Pah Meto sangat berkaitan dengan orientasi budaya yang mereka anut berdasarkan sistem kepercayaan mereka terhadap hal-hal seperti Tuhan, kemanusiaan, alam, alam semesta, dan masalahmasalah filosofis yang berkaitan dengan keberadaan masyarakat adat Atoni Pah Meto itu sendiri. Pandangan dunia masyarakat adat Atoni Pah Meto membantu mereka untuk mengetahui posisi dan tingkah mereka dalam alam semesta. Mereka mempunyai kepercayaan yang kuat bahwa manusia itu berkuasa dan terpisah dari alam, mereka memperlakukan alam semesta sebagai milik mereka, alam semesta merupa- kan suatu tempat untuk melaksanakan keinginankeinginan dan harapan-harapan mereka.

Pandangan dunia mempengaruhi kepercayaan, nilai, sikap, penggunaan waktu, dan banyak aspek budaya lainnya. Pandangan dunia masyarakat adat Atoni Pah Meto merupakan bagian dari milieu (lingkungan) budaya Atoni Pah Meto itu sendiri. Pandangan dunia mempengaruhi kepercayaan, nilai, dan sikap yang menjadi rujukan bagi masyarakat adat Atoni Pah Meto tentang baik dan buruk, benar dan salah, sejati dan palsu, posistif dan negatif. Pandangan dunia masyarakat adat Atoni Pah Meto merupakan nilainilai budaya yang menentukan bagaimana mereka harus bersikap. Nilai-nilai budaya ini menentukan 
perilaku-perilaku mana yang penting dan perilakuperilaku mana yang harus dihindari. Nilai-nilai budaya ini merupakan seperangkat aturan terorganisasikan untuk membuat pilihan-pilihan dan menciptakan harmonisasi atau mengurangi konflik dalam suatu masyarakat.

Berkenaan dengan pandangan dunia Atoni Pah Meto, maka perlu dibahas untuk mendapatkan informasi tentang keyakinan dan sikap hidup masyarakat adat Atoni Pah Meto. Keyakinan dan sikap hidup masyarakat adat Atoni Pah Meto tidak terlepas dari keberadaan faot kanaf dan oe kanaf, hau teas atau hau monef, sonaf (rumah adat suku), dan sistem pengelolaan sumber daya alam sebagai simbol budaya yang sangat dihormati, bahkan sangat dikeramatkan oleh masingmasing suku pemiliknya.

\section{METODE PENELITIAN}

Penelitan ini menggunakan paradigma konstruktivis dengan metode etnografi komunikasi yang berisi bagaimana peneliti melihat realita (world views), bagaimana mempelajari fenomena, cara-cara yang digunakan dalam penelitian dan cara-cara yang digunakan dalam menginterpretasikan temuan. Pendekatan penelitian etnografi komunikasi, yaitu penerapan dari metode-metode etnografi pada pola-pola atau cara-cara berinteraksi atau berkomunikasi dalam setiap peristiwa atau proses komunikasi dalam kelompok masyarakat. Masyarakat yang dimaksudkan dalam hal ini adalah kelompok masyarakat Atoni Pah Meto yang menjalankan komunikasi ritual dalam berbagai kegiatan mereka.

Hasil penelitian sangat tergantung pada kemampuan peneliti untuk menggambarkan dan menjelaskan bagaimana Atoni Pah Meto sebagai pelaku ritual tersebut membentuk realitas mereka sendiri sehingga terbiasa dengan ritual. Dalam konteks ini, tugas peneliti adalah mencari data dan menganalisisnya dari sudut pandang Atoni Pah Meto sehingga akan terlihat bagaimana dinamika sosial membentuk pemahaman mereka tentang ritual. Dengan demikian, peneliti mencoba menginterpretasikan temuan berdasarkan cara pandang yang digunakan oleh Atoni Pah Meto. Intinya paradigma ini berusaha mengungkap bagaimana (how) realitas sosial dibentuk dan dipertahankan oleh individu tertentu dan bagaimana mereka memaknainya. Informan kunci adalah tokoh masyarakat dan tokoh informal yang berperan sebagai maveva (juru bicara adat) maupun tobe (orang yang berwenang atas tanah adat). Para nara sumber atau informan kunci tersebut penulis tentukan berdasarkan pemahaman mereka masing-masing tentang data dan masalah penelitian tertentu yang penulis dalami. Adapun sejumlah nara sumber yang peneliti pilih adalah mereka yang memahami secara komprehensif sejarah, sistem kekerabatan, dan struktur masyarakat adat Atoni Pah Meto.

Teknik penggumpulan data berdasarkan pendapat Creswell dalam Kuswarno (2008:47), yakni menggunakan tiga teknik utama pengumpulan data dalam studi etnografi komunikasi, yaitu partisipan observer, wawancara mendalam dan telaah dokumen. Dalam Observasi terlibat (Participant Observation), adalah strategi lapangan yang secara simultan memadukan analisis dokumen, wawancara, partisipasi dan observasi langsung sekaligus dengan introspeksi. Sehubungan dengan hal ini, maka dalam penelitian lapangan peneliti turut terlibat langsung ke dalam berbagai aktivitas yang dilakukan oleh komunitas masyarakat adat Atoni Pah Meto. Melalui teknik ini, sebagaimana peneliti laksanakan, peneliti berupaya untuk masuk dalam kehidupan simbolik masyarakat adat Atoni Pah Meto untuk dapat mengetahui secara pasti logika subjektif seperti apakah yang dibangun di antara masyarakat adat Atoni Pah Meto pada umumnya, khususnya di Desa Oesena yang menjadi tempat penelitian. Sementara itu, wawancara mendalam (Indepth Interview) dilakukan dengan tujuan mengumpulkan keterangan atau data mengenai objek penelitian yaitu komunikasi informan dalam kesehariannya di lingkungan Atoni Pah Meto. Analisis Dokumen (Document analysis), dilakukan untuk menemukan gambaran mengenai pengalaman hidup atau peristiwa yang terjadi, beserta penafsiran subjek penelitian terhadapnya. Dokumen yang digunakan peneliti adalah dokumen-dokumen berupa catatan-catatan yang berlaku dalam masyarakat adat Atoni Pah Meto yang ada kaitannya dengan komunikasi ritual dalam budaya pertanian mereka.

\section{HASIL PENELITIAN DAN PEMBAHASAN}

Pandangan hidup atau pandangan dunia masyarakat adat Atoni Pah Meto sangat berkaitan dengan orientasi budaya yang mereka anut berdasarkan sistem kepercayaan mereka terhadap hal-hal seperti Tuhan, kemanusiaan, alam, alam semesta, dan masalahmasalah filosofis yang berkaitan dengan keberadaan masyarakat adat Atoni Pah Meto itu sendiri. Pandangan dunia masyarakat adat Atoni Pah Meto membantu mereka untuk mengetahui posisi dan tingkah mereka dalam alam semesta.

Menurut Mulyana dan Rakhmat (2006:28) isu-isu pandangan dunia bersifat abadi dan merupakan 
landasan paling mendasar dari suatu budaya. Seorang Katolik tentu saja mempunyai suatu pandangan dunia yang berbeda dibandingkan dengan seorang Muslim, Yahudi, atau seorang Ateis. Pandangan dunia orangorang Indian Amerika tentang kedudukan manusia dalam alam semesta tentu sangat berbeda dengan pandangan orang-orang Amerika asal Eropa kelas menengah tentang hal yang sama. Demikian pula pandangan dunia Atoni Pah Meto berbeda dengan pandangan dunia dari kelompok masyarakat lainnya.

Pandangan dunia masyarakat adat Atoni Pah Meto merupakan nilai-nilai budaya yang menentukan bagaimana mereka harus bersikap. Nilai-nilai budaya ini menentukan perilaku-perilaku mana yang penting dan perilaku-perilaku mana yang harus dihindari. Nilai-nilai budaya ini merupakan seperangkat aturan terorganisasikan untuk membuat pilihan-pilihan dan mengurangi konflik dalam suatu masyarakat. Berkenaan dengan pandangan dunia Atoni Pah Meto, maka perlu dibahas untuk mendapatkan informasi tentang keyakinan dan sikap hidup masyarakat adat Atoni Pah Meto, yakni: faot kanaf dan oe kanaf, hau teas atau hau monef, sonaf (rumah adat suku), dan sistem pengelolaan sumber daya alam sebagai simbol budaya yang sangat dihormati, bahkan sangat dikeramatkan oleh masing-masing suku pemiliknya.

\subsection{Faot Kanaf dan Oe Kanaf dalam World View Atoni Pah Meto}

Dalam bahasa Meto (Uab Meto), faot kanaf dan oe kanaf berasal dari tiga kata dasar yakni 'faot' atau 'fatu' yang berarti 'batu', dan 'kanaf berarti 'suku', serta 'oe' yang berarti 'air'. Dengan demikian, maka secara harafiah, faot kanaf atau fatu kanaf adalah 'batu suku', sedangkan oe kanaf adalah 'air suku'. Bagi masyarakat adat Atoni Pah Meto, faot kanaf dan oe kanaf dipahami sebagai batu atau gunung batu karang serta sumber air yang suci dan sakral. Kesucian dan kesakralan faot kanaf dan oe kanaf tersebut menjadikan eksistensi faot kanaf dan oe kanaf sebagai simbol budaya yang sangat dihormati, bahkan sangat dikeramatkan oleh masing-masing suku pemiliknya. Faot kanaf dan oe kanaf juga dipandang sebagai pusat lokasi ritual adat yang memiliki kesaktian atau kekuatan magis religius. Saktinya kekuatan magis religius yang melekat pada faot kanaf dan oe kanaf diyakini sangat besar pengaruhnya bagi kehidupan masyarakat adat Atoni Pah Meto. Hal yang sama juga diungkapkan oleh Kondradus (2007:1-2).

Faot kanaf dan oe kanaf bagi masyarakat adat Atoni $P a h$ Meto merupakan sebuah awal keberadaan sebuah suku, sehingga menjadi keyakinan dasar dan mereka percaya bahwa faot kanaf dan oe kanaf sebagai sumber kekuatan bagi keberlangsungan hidup masing-masing suku. Keyakinan dan sikap hidup masyarakat adat Atoni Pah Meto tidak terlepas dari kekuatan mitos tentang asal-usul masing-masing suku. Menurut mitos, pada saat leluhur tiba di suatu tempat, maka tempat tersebut dijadikan kuan atau perkampungan. Ketika proses menemukan atau menentukan kuan oleh para leluhur mereka selalu membawa benda-benda keramat (sebuah batu, segumpal tanah, sedikit air dalam sebuah wadah, sejumlah akar dan dedaunan pohon tertentu, serta gong). Pada tempat tesebut, mereka menanam batu dan air pada titik tertentu. Tempat tersebut sebagai lokasi faot kanaf dan oe kanaf (batu suku dan sumber air suku).

Berdasarkan sejarah yang dituturkan oleh Raja Bana Naineno II, disebutkan bahwa pada masa berlangsungnya migrasi dahulu, pada lokasi-lokasi faot kanaf dan oe kanaf para leluhur masyarakat adat Atoni Pah Meto menggantungkan benda-benda pusaka mereka. Benda-benda pusaka peninggalan para leluhur masing-masing suku tersebut diyakini memiliki kesaktian atau kekuatan gaib yang dapat saja membawa keberuntungan maupun musibah atau malapetaka bagi anggota warga suku. Dengan mengacu pada tuturan historis dan pengalaman peneliti sendiri yang terlibat dalam pelaksanaan ritual, serta dengan mencermati sejumlah fenomena sosial yang tetap dipertahankan keberadaannya hingga saat ini di tengah-tengah kehidupan masyarakat adat Atoni Pah Meto, maka peneliti memahami bahwa keberadaan faot kanaf dan oe kanaf dapat dipandang sebagai salah satu titik sentral kehidupan masyarakat adat Atoni Pah Meto. Peranan faot kanaf dan oe kanaf adalah sebagai jati diri dan penentu otoritas suku-suku di kalangan masyarakat adat Atoni Pah Meto. Hal ini sangat berhubungan dengan kisah pengembaraan para leluhur masyarakat adat setempat pada jaman dahulu dalam rangka mencari pusat atau poros bumi Pulau Timor.

\subsection{Hau Teas atau Hau Monef dalam World View Atoni Pah Meto}

Tiang kayu bercabang tiga yang biasanya didirikan di samping sebelah timur sebuah sonaf (rumah adat suku) disebut Hau teas atau hau monef. Hau teas atau hau monef adalah tiang pemujaan yang biasanya digunakan oleh masyarakat adat Atoni Pah Meto untuk melakukan ritual-ritual adat. Hau teas atau hau monef merupakan simbol dari tiga kekuatan supra 
natural yakni Uis Neno (Tuhan, Dewa Langit Yang Tinggi), Uis Pah (Tuhan, Dewa Bumi, Dewa Tanah), dan Be'i nai (arwah leluhur).

Masyarakat adat Atoni Pah Meto percaya bahwa restu surgawi hanya dapat diperoleh melalui wahyu Uis Neno dan Uis Pah melalui Be'i nai yang ada di pah maisokan (dunia gelap, alam gaib). Menurut kepercayaan Atoni Pah Meto, alam tempat manusia mempertahankan hidup berada di dalam otoritas Uis Neno dan Uis Pah. Oleh karena itu untuk menjalankan kegiatan ritual harus memohon ijin pada pemilik otoritas tersebut melalui Be'i nai (arwah leluhur) yang ada di pah maisokan (dunia gelap, alam gaib). Konsekuensi dari kepercayaan tersebut adalah setiap upaya manusia untuk mencari nafkah, mempertahankan hidup di dunia, harus dengan niat dan sikap hidup ikhlas. Dengan demikian, Masyarakat adat Atoni Pah Meto dituntut untuk memiliki kemampuan membangun dan membina harmoni dengan sesama dan Sang Pencipta. Hal tersebut merupakan merupakan upaya sadar yang dilakukan oleh masyarakat adat Atoni Pah Meto untuk mendapatkan restu surgawi, yang hanya melalui wahyu Uis Neno dan Uis Pah melalui Be'i nai.

\subsection{Sonaf (Rumah Adat Suku) dalam World View Atoni Pah Meto}

Sonaf atau rumah adat suku. Sonaf dipandang sebagai simbol pokok kehidupan suku. Sonaf bagi kehidupan masyarakat adat Atoni Pah Meto sesungguhnya tidak jauh berbeda baik dari segi arti, nilai, serta fungsi rumah adat pada umumnya dalam hubungannya dengan kehidupan dan interaksi sosial masyarakat tradisional di berbagai tempat. Secara sosio-antropologis misalnya, sonaf atau rumah adat suku bagi kelompok masyarakat adat Atoni Pah Meto selain memiliki nilai dan fungsi sosial ekonomis, tetapi juga nilai dan fungsi sosial keagamaan, dan sosial politis.

Elemen dasar pola sosialitas manusia tradisional sesungguhnya memberi tekanan pada nilai kebersamaan dan persatuan yang di dalamnya melingkupi pelbagai aspek vitalitas manusia untuk hidup dan berkembang. Selain itu, dengan berbagai ritual dan simbol-simbol yang ada di dalam rumah, masyarakat tradisional mengungkapkan dirinya, baik secara horisontal maupun vertikal (Amsikan 1992:149). Dengan demikian, sonaf adalah simbol persatuan, karena sonaf menjadi tali pengikat semua anggota suku. Selain itu, sonaf juga merupakan inti dan pusat kehidupan mereka. Sonaf sebagai inti dan pusat kehidupan kelompok masyarakat adat Atoni Pah
Meto hanya bisa dibangun dengan cara membersihan lokasinya dengan menggunakan oe le'u.

Secara sosio-ekonomis, sonaf bagi masyarakat adat Atoni Pah Meto merupakan simpul yang mengikat seluruh warga suku untuk membangun kebersamaan, persatuan, dan persekutuan hidup, selain sebagai salah satu titik sentral pelaksanaan ritual-ritual adat tertentu, termasuk ritual adat yang berkenaan dengan kegiatan sosial ekonomi masyarakat. Oleh karena itu pada $n i$ ainaf selalu ada lukisan padi, jagung dan pada ni ainaf selalu ada ikatan batang jagung atau bulir padi.

Ritual syukur atas panen yang dilaksanakan setiap tahun, pada tingkat kanaf (suku) dilaksanakan di sonaf, tepatnya pada ni ainaf yang ada di dalam sonaf maupun pada hau monef atau hau teas. Di kaki hau monef atau hau teas terdapat pula sejumlah batu yang disusun dengan rapi untuk meletakkan persembahan yang biasanya berada tepat di sebelah timur sonaf. Setelah pelaksanaan ritual adat syukur atas hasil panen yang baru. Saat itulah para anggota ume nakaf atau warga kanaf (suku) makan hasil panen terbaru yang ditandai dengan mencopot beberapa batang jagung atau beberapa bulir padi yang diikat pada $n i$ ainaf pada tahun sebelumnya dan menggantikannya dengan beberapa batang jagung atau beberapa bulir padi yang diambil dari hasil panen yang baru. Sonaf merupakan pusat kegiatan ritual sekaligus menjadi pusat pertobatan adat di mana seluruh anggota suku dapat berkumpul untuk melakukan rekfleksi rohaniah terhadap seluruh aktivitas dalam kehidupannya agar tercapai pola kehidupan yang harmonis.

Secara sosio-politis, sonaf memiliki nilai dan fungsi sebagai sumber kekuatan, perlindungan, rasa aman, kedamaian, serta keutuhan bagi seluruh anggota suku. Berbagai bentuk musyawarah adat dapat dilaksanakan dengan cara duduk bersama mengelilingi faot kanaf dan oe kanaf maupun ni ainaf yang ada di dalam sonaf tiap-tiap suku.

Secara sosio-religius, sonaf merupakan satu kesatuan simbol perayaan dan peringatan kepada arwah leluhur secara vertikal dalam rangka membangun dan menjamin keharmonisan hubungan dengan dunia atas, roh-roh dan arwah para leluhur, sementara secara horisontal sebagai simbol pemersatu untuk memperbaiki hubungan antara sesama anggota suku. Sonaf merupakan simbol alam raya yang integral, karena melalui sonaf masyarakat adat Atoni Pah Meto mampu mengungkapkan keberadaannya di dunia kini, dunia kemarin, dan bahkan dunia akan datang. 


\subsection{Tanah dalam World View Atoni Pah Meto}

Masyarakat Atoni Pah Meto mempunyai pengetahuan yang luas dan mendalam mengenai alam dan lingkungan disekitarnya termasuk unsur-unsur alam yang memiliki daya dan kekuatan bagi kehidupan manusia. Hal ini terbukti dari pelaksanaan berbagai ritual adat yang dipraktikan oleh masyarakat adat Atoni Pah Meto. Masyarakat adat Atoni Pah Meto adalah masyarakat yang menganut kepercayaan atau agama pemujaan terhadap roh (halaika). Bagi mereka roh ada di mana-mana. Kepercayaan ini merupakan realitas yang dipandang sebagai sesuatu yang rasional. Masyarakat adat Atoni Pah Meto percaya terhadap keberadaan dan kekuatan roh-roh di alam semesta ini, salah satu roh dalam konteks budaya pertanian tradisional masyarakat adat Atoni Pah Meto adalah roh penguasa bumi atau penguasa tanah, yang oleh masyarakat adat setempat disebut Uis Pah (Tuhan, Dewa Bumi atau Dewa Tanah).

Kepercayaan, penghormatan, dan pemujaan terhadap keberadaan dan kekuatan roh penguasa bumi atau tanah yang dikenal sebagai Uis Pah oleh masyarakat adat Atoni Pah Meto tersebut berkaitan dengan kondisi realitas tanah dengan eksistensi kesuburannya yang dapat menumbuhkan, mengembangkan, dan menghasilkan berbagai macam tanaman, tumbuhtumbuhan, pepohonan, bahkan sumber air dan mineral yang sangat bermanfaat bagi kehidupan berbagai makhluk hidup, khususnya bagi kehidupan umat manusia. Fungsi atau peran tanah yang demikian vital bagi kehidupan masyarakat adat Atoni Pah Meto, sehingga penguasa tanah yakni Uis $P a h$ oleh masyarakat adat Atoni Pah Meto senantiasa dihormati berupa 'pendewaan terhadap kekuatan bumi'. Kepercayaan yang menonjolkan penekanannya pada pendewaan terhadap kekuatan bumi tersebut, sesungguhnya merupakan salah satu kepercayaan terpenting yang mendasari semua hukum yang berkenaan dengan bumi. Dalam konteks ini, hakikat dewa bumi telah menjiwai berbagai norma adat Atoni Pah Meto yang berkenaan dengan tanah, baik norma adat yang berhubungan dengan pemahaman masyarakat tentang fungsi dan peran tanah bagi manusia, maupun berbagai norma adat yang mengatur tentang bagaimana seharusnya manusia berinteraksi dengan tanah atau bumi serta semua komponen lain yang ada di alam semesta ini. Berkenaan dengan fungsi dan peran tanah bagi kehidupan Atoni Pah Meto, maka usaha untuk berhubungan dengan kekuatan roh-roh yang ada di alam semesta oleh masyarakat adat Atoni Pah Meto adalah melalui ritual pemujaan terhadap arwah para leluhurnya.
Mengutip Kondradus (2007:386) sebagai ilustrasi, dalam berbagai mitos tentang kehidupan manusia pada jaman dahulu, ditemukan sejumlah kisah yang sangat kejam mengenai upaya manusia untuk mengorbankan sesama manusianya demi menghormati atau memberi makan roh ataupun dewa yang dipujanya. Mitos Liurai-Sonbai adalah sebuah mitos yang sangat populer di kalangan masyarakat adat Atoni Pah Meto, yang mengedepankan nilai dan semangat patriotisme serta cinta kasih yang luar biasa kepada sesama manusia dan tanah air, yang dimiliki oleh seorang putri raja. Dalam mitos tersebut dikisahkan bahwa, Raja Sonbai mengorbankan saudarinya Bi Sobe Leu di kebun Noelfael. Peristiwa pengorbanan putri raja tersebut segera diikuti turunnya hujan yang sangat lebat di seluruh negeri. Potongan tubuh putri raja, Bi Sobe Leu yang ditanam di seluruh kebun Noelfael kemudian berubah menjadi tanaman jagung, padi, kayu cendana dan tanaman bahan makanan lainnya, bahkan lebah hutan yang memberikan sari madu dan lilinnya bagi kehidupan para leluhur masyarakat adat Atoni Pah Meto.

Isi mitos Liurai Sonbai, mengisahkan tentang nilai patriotisme dan kasih sayang kepada sesama manusia, serta cinta tanah air yang dimiliki putri raja Bi Sobe Leu. Pengorbanan Bi Sobe Leu yang penuh kasih sayang dan patriot ini, menyebabkan masyarakat adat Atoni Pah Meto menaruh rasa hormat yang tinggi yang terwujud pada sikap hormat dan perlakukan yang sangat istimewa kepada pelbagai tanaman bahan makanan lokal di kalangan masyarakat adat Atoni Pah Meto. Mitos tentang Bi Sobe Leu menjadi bagian yang tidak bisa dipisahkan dengan pelaksanaan berbagai ritual adat di kalangan masyarakat adat Atoni Pah Meto yang tetap mengedepankan korban sembelihan berupa sejumlah hewan piaraan. Sehubungan dengan ritual yang selalu mengedepankan korban ini, maka tentu saja harus dipahami secara kontekstual. Hal ini perlu dilakukan untuk mencermati hubungan yang ada di antara berbagai fenomena sosial yang terjadi, agar kita dapat memiliki pemahaman yang benar tentang nilai-nilai luhur yang ada di balik sejumlah perilaku masyarakat adat dalam melaksanakan ritual adatnya.

Upaya yang dilakukan oleh masyarakat adat Atoni Pah Meto untuk mewujudnyatakan keberadaan dewa bumi atau dewa tanah di tengah-tengah kehidupannya, terlihat sangat jelas dalam rangkaian pelaksanaan ritual adat tatam pen tauf atau ritual persembahan sesajian kepada Uis Pah, sebagai puncak dari keseluruhan siklus aktivitas pertanian tradisional yang dilakukan oleh masyarakat adat Atoni Pah Meto. 
Praktik adat dalam hal mempersembahkan husufa atau upeti berupa pena pupun ane pupun (jagung dan padi pilihan) kepada usif dimaksud, sesungguhnya dilatarbelakangi oleh pandangan masyarakat adat Atoni Pah Meto tentang hakikat keberadaan dan peran yang melekat dalam diri seorang usif. Bagi masyarakat adat Atoni Pah Meto, keberadaan seorang usif sesungguhynya tidak hanya dipandang sebagai figur tokoh yang mengemban tugas sebagai kepala adat di tingkat kanaf (suku), tetapi juga menjadi kepala adat untuk seluruh masyarakat yang tinggal dalam sebuah kuan (perkampungan tradisional). Dalam konteks budaya pertanian yang dipraktikkan oleh masyarakat adat Atoni Pah Meto, mereka memandang usif sebagai representasi Uis $P a h$ yang seringkali juga dikenal dan disapa sebagai Pah Tuaf (tuan tanah) yang adalah sumber kekuatan luar biasa yang dianggap memiliki otoritas atas kesuburan tanah dan hasil bumi pada umumnya.

Makna dan nilai tanah dalam bingkai pengetahuan atau kearifan masyarakat adat Atoni Pah Meto, sesungguhnya dapat ditemukan melalui pelaksanaan berbagai ritual adat yang berkaitan dengan budaya pertanian. Berbagai ritual adat dimaksud, ternyata tidak pernah lepas dari orientasi masyarakat adat Atoni Pah Meto. Pelaksanaan berbagai ritual sarat dengan penggunaan beragam simbol yang sangat kaya akan makna-makna tindakan simbolisnya. Pada dasarnya makna dan nilai tanah bagi kehidupan Atoni Pah Meto sebagai petani tidak dapat dipisahkan dari sistem religi yang dimiliki dan dihayatinya. Kearifan lokal masyarakat adat Atoni Pah Meto tentang makna tanah bagi kehidupannya tersebut, sesungguhnya dilatarbelakangi oleh keberadaan dan peran dari sejumlah mitos yang mereka percayai, sejumlah ritual adat yang senantiasa mereka rayakan, serta sejumlah etika yang mereka taati atau patuhi secara bersamasama. Pengetahuan masyarakat adat Atoni Pah Meto tentang makna dan nilai tanah bagi kehidupannya di tengah-tengah alam semesta ini, berisikan berbagai norma adat yang mengatur bagaimana sesungguhnya masyarakat adat setempat seharusnya berinteraksi dengan lingkungan alam di sekitarnya mengandung sejumlah nilai luhur yang menjadi acuan budaya masyarakat adat Atoni Pah Meto. Nilai-nilai budaya yang sangat luhur tersebut saling terkait dan saling menopang dalam ikut membentuk karakter budaya masyarakat adat Atoni Pah Meto, terutama karakter budaya pertanian lahan kering yang dilakukan secara tradisional. Adapun nilai-nilai budaya yang luhur tersebut antara lain adalah nilai spiritual atau nilai religius, nilai ekologis, dan nilai persatuan.

\subsection{Tanaman dalam World View Atoni Pah Meto}

Pandangan masyarakat adat Atoni Pah Meto tentang makna dan nilai tanaman yang berhubungan dengan lingkungan alam di sekitarnya sangat berhubungan dengan sistem religi yang dimiliki dan dihayati dalam kehidupan Atoni Pah Meto. Tanaman bagi Atoni Pah Meto tidak dapat dipisahkan dari keberadaan dan peran dari sejumlah mitos yang dipercayai, dimiliki, dihayati, dan dijalankan dalam keseharian hidup masyarakat adat setempat, bahkan terus dituturkan atau diwariskan secara turun-temurun. Hal ini terkait dengan keberadaan mitos, yang tidak saja dipandang sebagai kisah suci tentang kehidupan para dewa atau wujud-wujud kekuatan supranatural lainnya, tetapi juga peran mitos yang dijadikan sebagai peletak dasar dari alam semesta. Mitos, dengan demikian, ternyata sangat berperan dalam mengatur dan mengendalikan keteraturan dan tata tertib di dalam alam atau jagat raya ini, sekaligus menjadi pedoman bagi manusia untuk bertingkah laku dalam kehidupan bermasyarakat.

Sesungguhnya mitos telah menawarkan cara berada dan bertingkah laku bagi manusia dalam ruang dan waktu. Dalam konteks yang sama, dapat dipahami pula, bahwa mitos telah memberikan kontribusi yang sangat berarti bagi manusia, terutama dalam hal ketersediaan informasi berupa sistem pengetahuan lokal (local knowledge system) yang berhubungan dengan pentingnya peranan tanaman (flora) dan hewan (fauna), bagi eksistensi dan kelanjutan hidup manusia. Masyarakat adat Atoni Pah Meto, memiliki sejumlah mitos yang terus dipercaya, dihayati, dan bahkan dijalankan dalam kehidupan sehari-hari hingga saat ini. Keberadaan dan peran dari sejumlah mitos dalam kehidupan masyarakat adat Atoni Pah Meto hingga saat ini, dapat ditelusuri melalui pelbagai ritual adat, terutama ritual-ritual yang terkait dengan budaya pertanian, di lokasi faot kanaf-oe kanaf masing-masing suku.

Ritual-ritual adat yang terkait dengan pengetahuan, pemahaman, dan perlakuan masyarakat adat Atoni Pah Meto terhadap tanaman di antaranya adalah ritual menebang pohon di lokasi calon lele tolas (kebun baru) dalam rangkaian ritual adat tafek nono hau ana (pembukaan kebun baru). Petani dalam lingkup masyarakat adat Atoni Pah Meto selalu melakukan identifikasi secara cermat terhadap seluruh tanaman hutan atau pepohonan yang ada di kawasan calon lele tolas. Kegiatan identifikasi terhadap seluruh tanaman hutan atau pepohonan yang ada di lokasi calon lele tolas tersebut dimaksudkan untuk mengetahui secara 
tepat, manakah tanaman hutan dan pepohonan yang boleh ditebang dan tanaman hutan atau pepohonan mana yang tidak boleh ditebang. Beberapa jenis pohon yang biasanya dibiarkan tetap hidup, antara lain adalah hau meni atau pohon cendana (Santallum Album), jenis pepohonan yang biasanya dijadikan sebagai tempat bersarangnya lebah hutan, dan jenisjenis kayu yang biasanya digunakan untuk membangun rumah seperti halnya kayu jati (Tectona Grandis), serta matani atau kayu merah (Pterocarpus Indicum) yang biasanya sangat tahan terhadap api. Proses identifikasi terhadap seluruh tanaman hutan atau pepohonan hutan sebagaimana disebutkan di atas, memang dilatarbelakangi oleh sejumlah pertimbangan, baik yang berhubungan dengan manfaat praktis terkait persiapan pengolahan lahan, maupun manfaat ekonomis lainnya yang diperuntukkan bagi para petani bersangkutan. Meskipun demikian, pada sisi lainnya harus diakui pula bahwa kegiatan identifikasi dimaksud justru sangat terkait erat dengan sistem religi yang dimiliki oleh masyarakat adat setempat, khususnya yang berhubungan dengan kepercayaan dan penghayatan mereka terhadap mitos hau meni atau kayu cendana (Santallum Album).

Adapun isi ringkas mitos hau meni atau kayu cendana (Santallum Album) yang dimiliki, dipercayai, dan terus saja dihayati oleh masyarakat adat Atoni Pah Meto dalam keseharian hidupnya hingga saat ini, adalah sebagai berikut. (Kondradus 2007:402).

"Adalah dua bersaudara laki-laki: Liurai Sonbai (Lilai Sonbai) dan Liurai Wewiku-Wehali yang datang ke Pulau Timor sebagai petani ladang. Setelah membuka ladang, mereka tidak mempunyai benih. Mereka menghadap Uis Neno (Tuhan) untuk meminta benih. Oleh Uis Neno mereka diberi api. Untuk mengambil api tersebut, pertama-tama, mereka menggunakan seutas tali, namun ternyata tali tersebut putus karena terbakar api. Kemudian, mereka menggunakan selembar kain selimut. Upaya ini pun berakhir dengan kegagalan. Selanjutnya, mereka menggunakan tangan kosong untuk mengambil api itu guna membakar ladang. Namun, upaya mereka ini pun gagal lagi, karena tangan mereka terbakar api. Melihat kebodohan mereka, Uis Neno memberinya lilin yang menyala. Dengan lilin itu mereka membakar ladang. Namun mereka belum memiliki benih. Mereka menghadap Uis Neno_lagi. Oleh Uis Neno, mereka diminta untuk mengorbankan adik perempuan mereka dengan cara mencincang dan menyebarkan daging dan darahnya di ladang. Kemudian tumbuhlah aneka tanaman. Dari otaknya ber- kembanglah lebah hutan yang menghasilkan madu dan dari tulangnya tumbuhlah pohon cendana.

Isi mitos hau meni di atas, membantu kita untuk memperoleh pemahaman yang lebih komprehensif tentang makna ritual adat tafek nono hau ana dalam praktik budaya pertanian masyarakat adat Atoni Pah Meto. Melalui isi mitos hau meni, kita dapat memahami bahwa sistem pengetahuan lokal (local knowledge system atau indigenous knowledge system) masyarakat adat Atoni Pah Meto yang berhubungan dengan etos lingkungannya telah dijadikannya sebagai acuan atau pedoman dalam berinteraksi dengan lingkungan alam yang ada di sekitarnya. Pemanfaatan sistem pengetahuan lokal (local knowledge system) untuk berhubungan atau berinteraksi dengan lingkungan alam yang ada di sekitarnya dapat ditelusuri melalui perilaku masyarakat adat dalam hal melakukan identifikasi terhadap berbagai jenis tanaman hutan atau pepohonan hutan, terutama perlakuan mereka terhadap hau meni atau kayu cendana.

Ritual adat tafek nono hau ana (pembukaan kebun baru) misalnya, praktik identifikasi terhadap berbagai tanaman atau pepohonan hutan, termasuk perlakuan masyarakat adat setempat terhadap hau meni atau kayu cendana, ternyata sangat erat kaitannya dengan sistem religi yang dianut, mereka menganggap hau meni atau kayu cendana sebagai penjelmaan dari seorang putri raja, yang rela mengorbankan dirinya untuk dibunuh dan dicincang sebagai korban sembelihan, atas restu dan campur tangan Uis Neno (Tuhan, Dewa Langit Yang Tinggi).

Kuatnya interaksi antara masyarakat adat Atoni Pah Meto dengan lingkungan alam yang ada di sekitarnya dalam bingkai sistem religi, sebagaimana terlihat dalam pelaksanaan berbagai ritual tafek nono hau $a n a$, ternyata selalu berpusat atau berorientasi pada faot kanaf-oe kanaf yang oleh masyarakat adat setempat dipandang sebagai simbol jati diri dan sumber kekuatan yang menghidupkan bagi masingmasing anggota suku. Besarnya peran dan pengaruh faot kanaf-oe kanaf sebagai simbol jati diri suku dan simbol otoritas suku, serta sumber kekuatan yang menghidupkan bagi setiap anggota masyarakat adat Atoni Pah Meto dalam pelaksanaan berbagai ritual adat, termasuk ritual-ritual adat yang berhubungan dengan budaya pertanian tradisional setempat, dapat ditemui pula dalam rumusan-rumusan onen (doa) adat yang selalu mereka ucapkan pada saat berlangsungnya ritual-ritual adat. 
Makna dan nilai tanaman sebagai bentuk lain dari pengetahuan lokal atau kearifan lokal masyarakat adat Atoni Pah Meto yang dapat ditelusuri melalui tahapan kegiatan penebangan pepohon di kawasan hutan calon lele tolas (kebun baru) dalam rangkaian ritual adat tafek nono hau ana. Maka, makna dan nilai tanaman dapat juga ditelusuri melalui berbagai ungkapan atau istilah-istilah adat tertentu, rumusanrumusan onen adat tertentu, bahkan urutan-urutan ritual adat serta tempat pelaksanaan ritual adat yang sangat dipengaruhi oleh berbagai kisah mitologis yang terus saja dipercayai, dihayati dan bahkan dijalankan hingga saat ini dalam konteks budaya pertanian tradisional masyarakat adat Atoni Pah Meto.

Masyarakat adat Atoni Pah Meto percaya bahwa tanaman 'jagung' dan 'padi' bukanlah sekadar sumber pangan biasa, bagi mereka, 'jagung' dan 'padi' adalah sumber makanan yang merupakan penjelmaan Bi Sobe Leu, putri raja yang rela berkorban demi rakyat yang sangat dicintainya. Kepercayaan masyarakat adat setempat tentang mitos Liurai-Sonbai tersebut demikian kuatnya dan bahkan sangat menjiwai seluruh aktivitas pertanian Atoni Pah Meto. Kepercayaan masyarakat adat Atoni Pah Meto terhadap mitos Liurai-Sonbai, terlihat dengan jelas dalam ritual-ritual pertanian yang memperlihatkan bagaimana mereka memperlakukan tanaman jagung dan padi semenjak saat penanaman, perawatan, hingga tibanya saat panen, bahkan sampai pada tahap merawat roh makanan.

Kepercayaan dan penghayatan masyarakat adat Atoni Pah Meto terhadap sejumlah mitos, mereka ekspresikan dalam ritual adat yang berkaitan dengan bidang pertanian, memang sulit diterima secara akal sehat. Meskipun demikian, dengan mengacu karya-karya para etnolog dalam penyelidikannya tentang kehidupan budaya masyarakat arkhais, khususnya tentang penghayatan mitos sebagai cerita tentang tindakan dewa-dewi, mereka justru menemukan bahwa sesungguhnya mitos itu dapat berfungsi untuk menyadarkan manusia tentang adanya kekuatan gaib atau kekuatan supranatural yang dapat mempengaruhi keadaan dunia dan tindakan manusia. Mitos juga memiliki fungsi sebagai pedoman yang menjamin kebutuhan eksistensi manusia di tengah ancaman dunia serta memberikan pengetahuan tentang dunia seperti halnya cerita-cerita tentang langit dan bumi, cerita tentang asal-usul manusia pertama, cerita tentang asal-usul nenek moyang, cerita tentang asalusul tanaman ladang, cerita tentang tindakan hewan tertentu yang menyelamatkan nenek moyang atau para leluhur dari sebuah kelompok masyarakat dan sebagainya. Pengetahuan masyarakat adat Atoni Pah Meto tentang makna dan nilai tanaman merupakan representasi dari pola-pola yang dikehendaki oleh wujud tertinggi, para dewa, dan arwah para leluhur yang harus dipatuhi oleh Atoni Pah Meto.

\section{KESIMPULAN}

Kesimpulan yang dapat ditarik dari penelitian ini adalah pandangan hidup atau pandangan dunia masyarakat adat Atoni Pah Meto sangat berkaitan dengan orientasi budaya yang mereka anut berdasarkan sistem kepercayaan mereka terhadap hal-hal seperti Tuhan, kemanusiaan, alam, alam semesta, dan masalah-masalah filosofis yang berkaitan dengan keberadaan masyarakat adat Atoni Pah Meto itu sendiri. Berikut kesimpulan yang dapat dibuat:

1. Berkenaan dengan pandangan dunia Atoni Pah Meto, maka keyakinan dan sikap hidup masyarakat adat Atoni Pah Meto, tidak terlepas dari keberadaan faot kanaf dan oe kanaf, hau teas atau hau monef, sonaf (rumah adat suku), dan sistem pengelolaan sumber daya alam sebagai simbol budaya yang sangat dihormati (makna tanah dan tanaman bagi Atoni Pah Meto).

2. Keberadaan faot kanaf dan oe kanaf bagi masyarakat adat Atoni Pah Meto diyakini sebagai tonggak sejarah keberadaan sebuah suku, sehingga masyarakat adat Atoni Pah Meto percaya bahwa faot kanaf dan oe kanaf sebagai sumber kekuatan bagi keberlangsungan hidup masingmasing suku.

3. Masyarakat adat Atoni Pah Meto percaya bahwa restu surgawi hanya dapat diperoleh melalui wahyu Uis Neno dan Uis Pah melalui Be'i nai yang ada di pah maisokan (dunia gelap, alam gaib). Bahwa setiap upaya manusia untuk mencari nafkah dalam rangka mempertahankan kehidupannya di atas dunia ini, haruslah dilakukan dengan niat hati dan sikap hidup ikhlas. Dengan demikian, Masyarakat adat Atoni Pah Meto dituntut untuk memiliki kemampuan membangun dan membina harmoni dengan sesama dan Sang Pencipta.

4. Sonaf atau rumah adat suku dipandang sebagai simbol pokok kehidupan suku. Secara sosioantropologis, sonaf atau rumah adat suku bagi kelompok masyarakat adat Atoni Pah Meto selain memiliki nilai dan fungsi sosial ekonomis, tetapi juga nilai dan fungsi sosial keagamaan, dan sosial politis.

5. Makna dan nilai tanah dalam bingkai pengetahuan atau kearifan masyarakat adat Atoni Pah Meto sangat berkaitan dengan nilai-nilai budaya yang luhur antara lain adalah nilai spiritual atau nilai religius, nilai ekologis, dan nilai persatuan. 
Pengetahuan masyarakat adat Atoni Pah Meto tentang makna dan nilai tanaman merupakan representasi dari pola-pola yang dikehendaki oleh wujud tertinggi, para dewa, dan arwah para leluhur yang harus dipatuhi oleh Atoni Pah Meto.

\section{DAFTAR PUSTAKA}

Adimihardja, Kusnaka. 1999. "Hak Sosial Masyarakat Adat" dalam "Menggugat Posisi Masyarakat Adat Terhadap Negara", Prosiding Sarasehan Masyarakat Adat Nusantara, Jakarta:1516 Maret. Sandra Kartika dan Candra Gautama (penyunting). Jakarta: Diterbitkan atas kerjasama Panitia Bersama Sarasehan dan Konggres Masyarakat Adat Nusantara 1999 dengan Lembaga Studi Pers dan Pembangunan (LSPP).

Amsikan, Aplonius.1992. "Rumah Adat Masyarakat Atoni Bukifan (Dawan-Timor Tengah Utara)" dalam "Agenda Budaya Pulau Timor 2", Piet Manehat \& Gregor Neonbasu (Editor). Kupang: Diterbitkan oleh Komisi Komunikasi Sosial Provinsi SVD Timor.

Bustan, F. 2010. Linguistik Kebudayaan. Bahan Ajar Mandiri. Kupang: Program Studi Magister (S2) Linguistik Program Pascasarjana Undana.

Clifford, James. 1988. "The Predicament of Culture: Twentieth-Century Ethnography, Literature, and Art'. Cambridge, Massachusetts: Harvard University Press.

Couldry, Nick. 2005. Media Rituals; Beyond Functionalism., dalam Media Anthropology. Editor: Eric W. Rothenbuhler dan Mihai Coman. Thousand Oaks: SAGE Publications.

Cunningham, Clark E. 1964. "Order in the Atoni House", Bijd. 120: 34-68.

Dahl, Jens et al. 2001. "Masyarakat Adat di Dunia: Eksistensi dan Perjuangannya". Judul asli: "Infodte Folk", (Copenhagen: IWGIA, 1992) oleh Zainab Geiger, Zurich, Switzerland. Edi Petebang (Ed.). Diterbitkan atas kerjasama International Work Group For Indigenous Affairs (IWGAI) Copenhagen, Denmark dan Institut Dayakologi (ID), Pontianak, Indonesia. Jakarta: PT Gramedia.

Kleden, Ignas. 1998. "Dari Etnografi ke Etnografi Tentang Etnografi: Antropologi Clifford Geertz dalam Tiga Tahap". Kata Pengantar dalam Clifford Geertz: After The Fact, Dua Negeri, Empat Dasawarsa, Satu Antropologi. Yogyakarta: Penerbit LKIS.

Kuswarno Engkus. 2008. Etnografi Komunikasi suatu Pengantar dan Contoh Penelitiannya. Widya Padjadjaran. Bandung

Manafe, Yermia, Djefri. 2013. Komunikasi Ritual Pada Pertanian Atoni Pah Meto(Studi Etnografi Komunikasi Tentang Budaya Bertani Atoni Pah
Meto Di Oesena Timor Tengah Utara - Nusa Tenggara Timur). Bandung: Disertasi S3, Program Pascasarjana Universitas Padjadjaran.

Middelkoop. Pieter. 1938. "Iets over Sonba'I, het bekende vorstengeslacht op Timor (Something about Sonba'I, The wellknown royal house on Timor)"', Tijd. 78:392-509.

1963. Headhunting in Timor and Its Historical Implications., Oceania Linguistic Monograph No. 8. Australia: University of Sidney.

1968. Migrations of Timorese Groups and The Question of Atoni Kase Metan or Overseas Black Foreigners. International Archiv of Ethnographic, Vol. LI, Leiden: E.J. Brill.

Moleong, Lexy J. 2005. Metodologi Penelitian Kualitatif (Edisi Revisi). Bandung: PT Remaja Rosdakarya.

Muhajir, Noeng. 1996. "Metodologi Penelitian Kualitatif', Yogyakarta: Rake Sarasin.

Mulyana, Deddy, 2006. Metodologi Penelitian Kualitatif. Bandung: Remaja Rosdakarya.

Deddy. 1995. Twenty Five Indonesians in Melbourne (Disertasi dalam rangka memperoleh Ph.D di Universitas Monash, Australia).

Parera. ADM. 1994. "Sejarah Pemerintahan RajaRaja Timor: Suatu Kajian Peta Politik Pemerintahan Kerajaan-Kerajaan Di Timor Sebelum Kemerdekaan RI’. Gregor Neonbasu, (Ed.). Jakarta: Diterbikan atas kerja sama PT Yanense Mitra Sejati dengan Pustaka Sinar Harapan.

Rakhmat, Jalaludin, 1997, Metode Penelitian Котиnikasi, Bandung Remaja Rosdakarya.

Spradley, James. P. 1980. "Participant Observation”. Orlando, Florida: Macalester College.

Suyino, Iman. 2006. Komunikasi Antaretnik Dalam Masyarakat Tutur Diglosik: Kajian Etnografi Komunikasi Etnik Using. Jurnal Penelitian Humaniora, Vol. 18. No. 3, 2006. Fakultas Ilmu Budayua Universitas Gajah Mada. Yogyakarta.

Udak, Urikame Blasius, dkk., 2003. "Karakteristik Pemerintahan Lokal Di Propinsi Nusa Tenggara Timur, Studi di Kabupaten Kupang, TTS, TTU, dan Belu'. Kupang: Percetakan PT. Praja Multi Pritindo. Diterbitkan atas kerjasama Yayasan Peduli Sesama (SANLIMA) dengan The Ford Foundation.

Usfinit, Un Alexander. 2003. "Maubes Insana: Salah Satu Masyarakat di Timor dengan Struktur Adat yang Unik'. Yogyakarta: Penerbit Kanisius. Diterbitkan atas kerjasama dengan Yayasan Adikarya Ikapi dengan The Ford Foundation.

Konradus, Blajan. 2007. "Faot Kanaf-Oe Kanaf Sebagi Representasi Etos Lingkungan (Kajian Etnoekologi tentang Kearifan Lokal Masyarakat Adat Atoni Pah Meto di Timor Barat-Provinsi Nusa Tenggara Timur). Surabaya: Disertasi S3, Program Pascasarjana Universitas Airlangga. 